MATEC Web of Conferences 9, 06001 (2013)

DOI: $10.1051 /$ matecconf/20130906001

(C) Owned by the authors, published by EDP Sciences, 2013

\title{
Fire performance of multi-storey wooden facades
}

\author{
Birgit A.-L. Östman and Lazaros D. Tsantaridis
}

\author{
SP Wood Technology Stockholm, Sweden
}

\begin{abstract}
Two series of full scale fire tests of wooden facades according to the Swedish test SP Fire 105 are presented, one series for different shares of untreated wood (partial wood and structural fire protection with a fire shield above the window) and another series for fire retardant treated, FRT, wood. The results are compared with data from the Single Burning Item test and the cone calorimeter.

For FRT wood, the need for verification of the weather durability of the treatment is stressed and a new European technical specification CEN/TS 15912 presented.

The need to use fire stops behind multi-storey façade claddings to avoid fire spread in the cavities is underlined and the possibilities of fire safety design with sprinklers is briefly presented.
\end{abstract}

\section{INTRODUCTION}

The introduction of performance based building codes has facilitated an extended use of timber structures in multi-storey buildings, e $\mathrm{g}$ in the Nordic countries, but the use of visible wood is still limited. Wood facade claddings are increasingly requested by architects as an esthetical feature not only in timber buildings. However, there is not yet a harmonised European system for the fire safety of facades, as for most other applications [1], even if many countries apply the reaction to fire classes [2], while some countries request additional national procedures [1]. In Sweden and to some extent also in the other Nordic countries a full scale facade test SP Fire 105 [3] is required by the building authorities.

There are three main fire scenarios for exterior claddings:

- a compartment fire at or after flashover with venting and flames out of a window

- an external fire in combustibles accumulated near the exterior wall (trash, vehicle, brush etc,)

- a fire in an adjacent building.

Of these, the first case is perceived to be the most intense and statistically most significant ignition source for exterior claddings. The second case is regulated in Finland and studies on wooden facades have been performed [4]. The third case is usually solved by a certain safety distance between buildings. Further studies on wooden facade fires include $[5,6]$.

The use of wooden facades is facilitated if the buildings are sprinkled. Residential sprinklers in apartments have been used for a long time in the US and have more recently been introduced in Scandinavia and also in the UK. Finland has requirements on sprinklers in timber frame buildings of 3-8 storeys. In Denmark and Sweden sprinklers are a clear option to increased use of wood in buildings. A Swedish national programme for the introduction of residential sprinklers has resulted in rules for alternative design, e g more visible wood in interior and exterior applications [7]. Other means to use more wooden facades are to limit the risk for upward flame spread along the facade surface. Such means may be fire rated windows with a fire resistance of at least 15 or 30 minutes, an automatic window shutter [8] and fire shields over windows, see below.

This is an Open Access article distributed under the terms of the Creative Commons Attribution License 2.0, which permits unrestricted use, distribution, and reproduction in any medium, provided the original work is properly cited. 


\section{MATEC Web of Conferences}

Table 1. Requirements based on data from the facade test SP Fire 105.

\begin{tabular}{|l|l|}
\hline Measurements in SP 105 & Requirement in the Swedish building code \\
\hline Gas temperature at eave: & $<500^{\circ}($ excl. 2 minutes $)$ or $<450^{\circ}($ excl. 10 minutes $)$ \\
\hline Heat flux at centre of: & \\
\hline - lower window & $<80 \mathrm{~kW} / \mathrm{m}^{2}$ \\
\hline - upper window & No requirements at present; $\left(<20 \mathrm{~kW} / \mathrm{m}^{2}\right.$ suggested $)$ \\
\hline Fire spread (charring) on facade & $<$ lower part of upper window \\
\hline Falling parts & No major parts, $<0,1 \mathrm{~m}^{2}$, no burning droplets \\
\hline
\end{tabular}

\section{FAÇADE FIRE TESTS}

In some countries, façade systems for multi-storey buildings must be tested in a specific façade test rig [1]. The facades must fulfil requirements on the spread of fire and the safety of fire brigades during fire fighting, and evacuation safety of occupants. Evaluation criteria include:

- no fire outside the initial fire area

- fulfilling temperature criteria in the rear ventilation spaces and ventilation voids

- no collapse of larger parts.

\section{SP Fire 105 - a full scale facade fire test for flame spread}

SP Fire 105 [3] is a full-scale fire test simulating a three-storey building with a fire from a room at the bottom floor. The fire source is 601 heptane. The test duration is about 15 to 20 minutes and the fire exposure exhibits a rise and decay that simulates real fire conditions. The measurements and the requirements are given in Table 1.

\section{Tests with partial wooden facades and fire shields}

The Swedish building code allows only up to about $20 \%$ of the facade area per storey to be covered by combustible claddings, e.g. wood, as a rule of thumb [8]. Higher amounts are highly requested by architects and building companies. Two series of facade fire tests according to SP Fire 105 have therefore been performed [9]. The first series consisted of partial untreated wood on the facade and the second one of fire retardant treated (FRT) wood.

Partial wood with about 33 and $60 \%$ of untreated wood (Nordic spruce) was used in two tests. In a third test, a fire shield above the fire window and $100 \%$ wood was used. The wood panels were $22 \mathrm{~mm}$ thick and mounted horizontally on vertical laths as lap sidings and with an air gap behind. The air gap was tightened around the windows as used in practise. Overviews of the test set-ups and results are given in Table 2 and Figure 1 [10]. Some comparisons of data are given in Figure 2.

The main conclusions on the façade fire tests for partial wood and fire shields are

- Failure criteria are damage at upper window, not temperature or heat flux levels

- Partial wood up to about 50\% may fulfil the requirements. The exact amount depends on the geometrical configuration of wood in relation to the windows

- A fire shield above the window stops the fire spread and allows for $100 \%$ wood to be used.

\section{Tests with FRT wooden facades}

Fire retardant treated, FRT, wood may have improved fire performance, but it is essential that the treatment is durable at exterior applications. A system with new so called service classes for the durability of the FR treatment in interior and exterior applications is being introduced, see below. 
$1^{\text {st }}$ International Seminar for Fire Safety of Facades, Paris (France), 2013

Table 2. Partial (untreated) wooden facades and fire shields. results according to SP Fire 105.

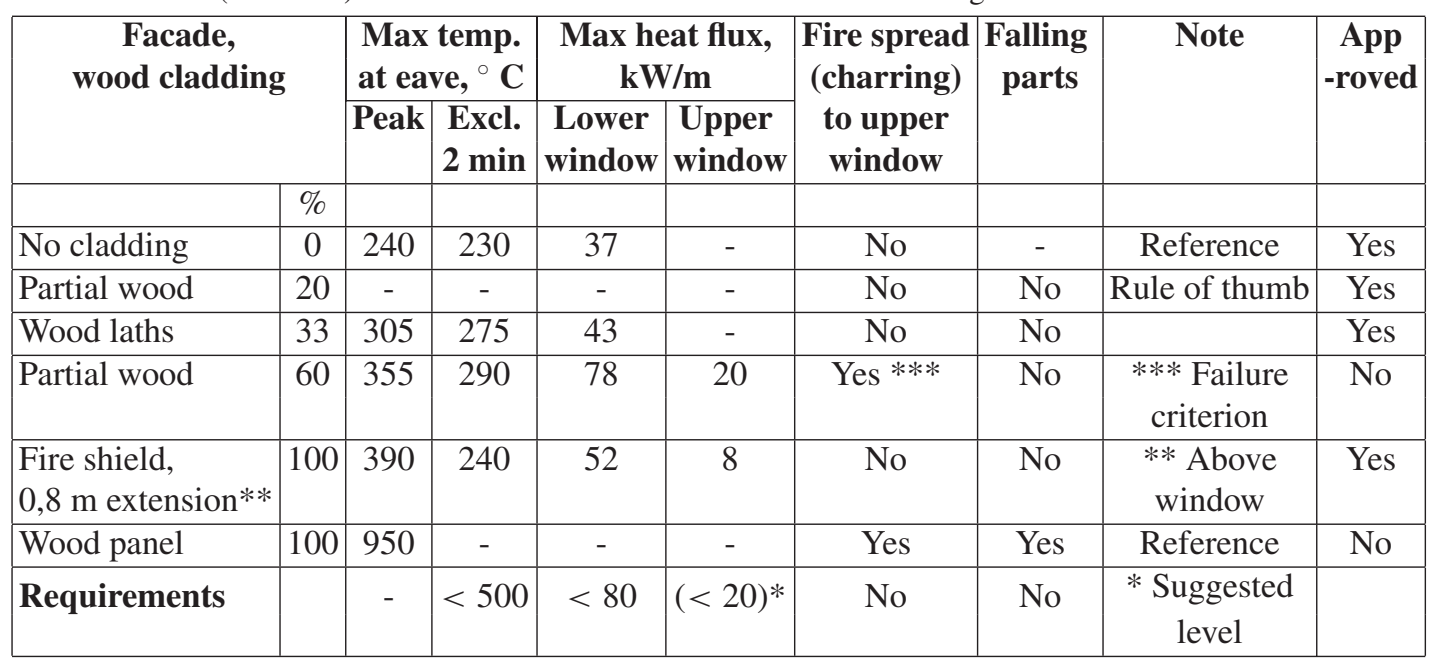

The fire performance of FRT wood has been investigated in a series of facade fire test according to SP Fire 105. The wood panels (Nordic spruce) $22 \mathrm{~mm}$ thick were pressure impregnated by the manufacturers and dried. Panels with a constant retention of FR were selected. The panels were mounted day as the untreated panels for the partial wood studies. Overviews of the test set up and results are given in Table 3 and Figures 3 and 4 [10]. Three types of fire retardants have been studied X, Y and $\mathrm{Z}$, the latter one at three retention levels. The influence of retention level is illustrated in Figure 5. The $\mathrm{Z}$ treatment is superior and the facade fire requirements fulfilled at all retention levels. Treatments $\mathrm{X}$ and $\mathrm{Y}$ do not fulfil these requirements due to damage at the upper window, see Figure 4, even if the temperatures at the eave is below the critical level $500^{\circ} \mathrm{C}$.

\section{COMPARISONS WITH SOME OTHER FIRE TEST DATA}

The full scale fire test results have been compared with the Single Burning Item test [11], the European fire test for the reaction to fire of all types of building products. SBI consists of an open corner figuration with upward flame spread and is used also for facade applications in many European countries [1]. The full scale data have been compared also with the cone calorimeter, ISO 5660 at $50 \mathrm{~kW} / \mathrm{m}^{2}$ irradiance level. The results have been expressed in terms of FIGRA - Cone, i.e. in the same way as for SBI. For the partial wood cases, direct comparisons have been performed based on cone calorimeter tests for partial wood with the wood replaced by fiber cement board, see Figure 6.

Comparisons for FRT wood panels are given in Figure 7, which shows a fair agreement between FIGRA - SBI and temperature at eave and heat flux in SP Fire 105.

Comparisons of fire classification data for the FRT wood panels are given in Table 4. Treatment Z has better performance, but the retention levels are usually higher than for the other treatments.

\section{DURABILITY OF THE REACTION TO FIRE PERFORMANCE}

The durability of the fire retardant treatments needs to be considered, especially for exterior applications. Two mechanisms affect the durability of FRT wood products [13]. Firstly, the risk of high moisture content and migration of the fire-retardant chemicals within the wood product and salt crystallisation on the product surface. Secondly, the risk of decreased fire performance due to loss of the fire retardant chemicals by leaching. These risks are highest for exterior applications and the main challenge to the development of new fire-retardant-treated (FRT) wood products. 
MATEC Web of Conferences

Untreated wood

Partial wooden facades and fire shields

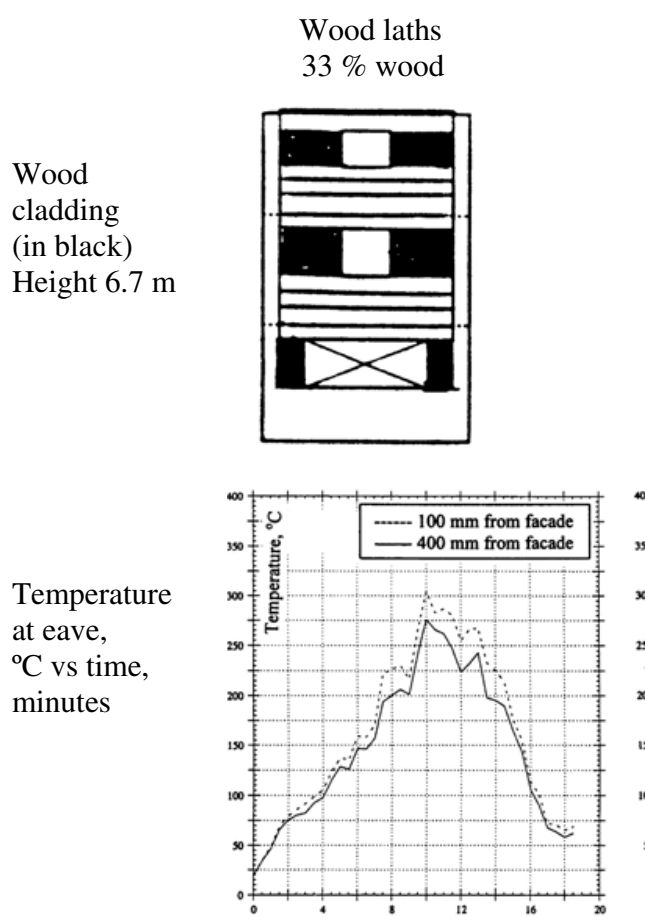

Heat flux at windows, $\mathrm{kW} / \mathrm{m}^{2}$

vs time, minutes

Damage (charring) after test
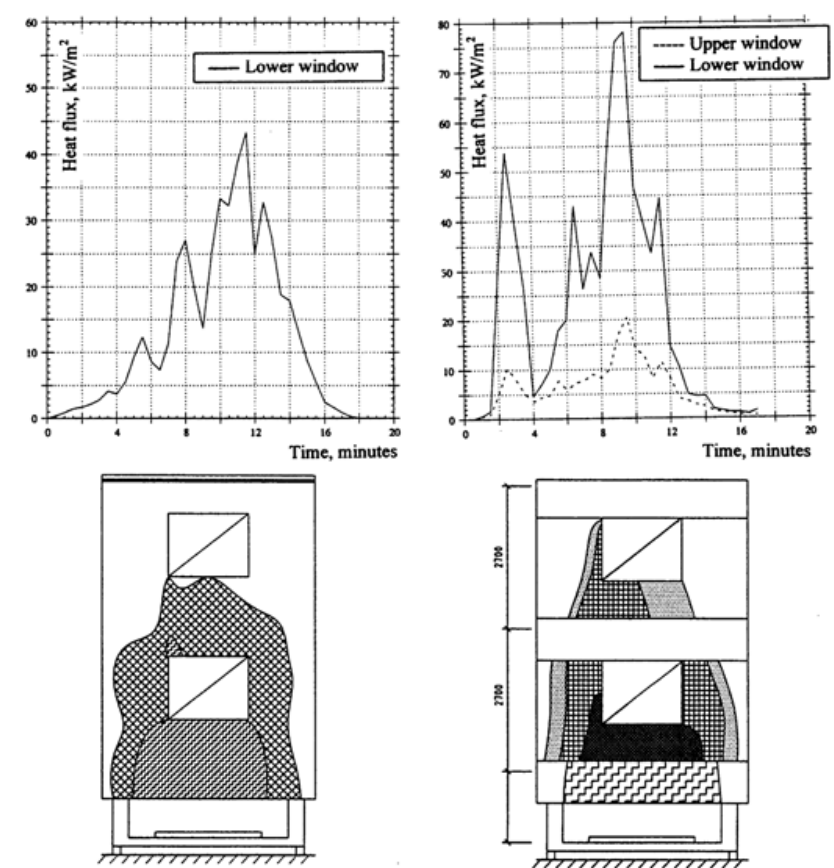

Partial wood

$60 \%$ wood
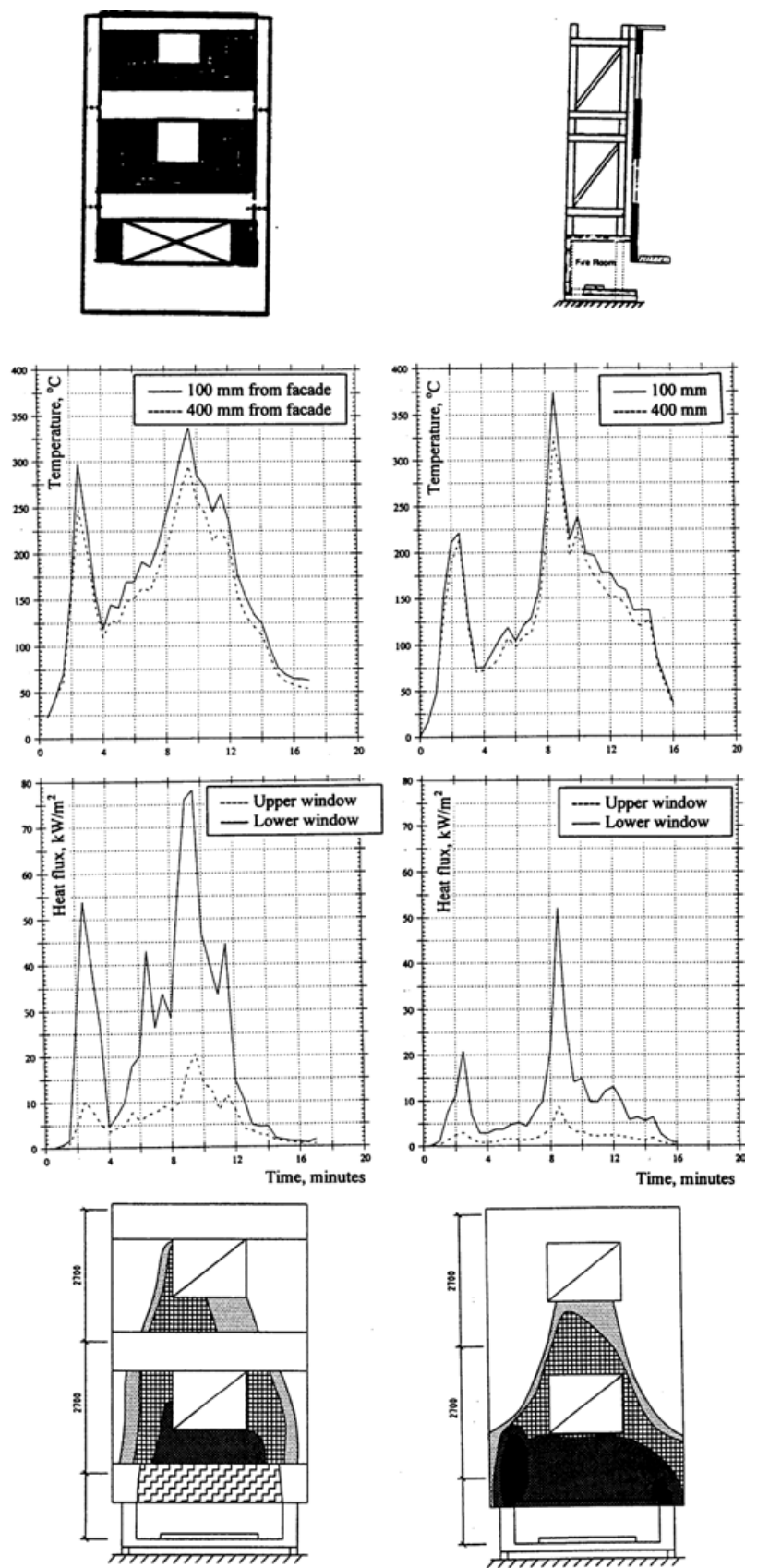

Fire shield above

window, $100 \%$ wood
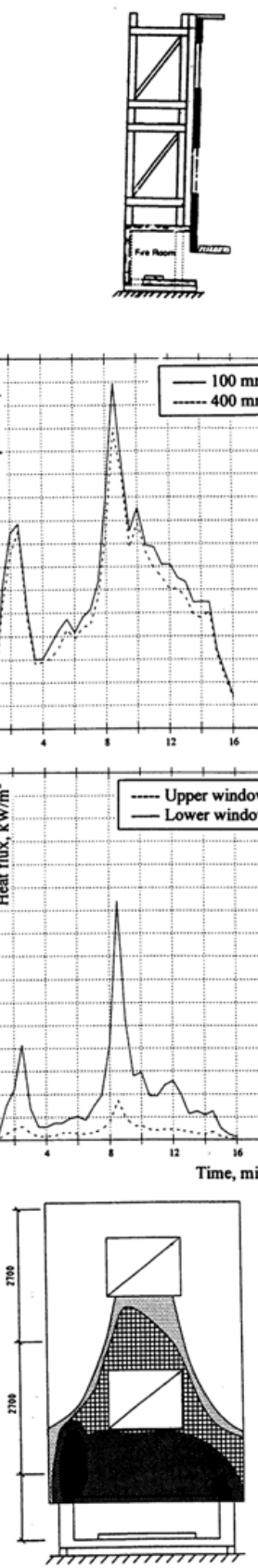

Figure 1. Facade tests according to SP Fire 105 with results for partial wood (to the left) and for fire shield with $0.8 \mathrm{~m}$ horizontal extension (to the right). 
$1^{\text {st }}$ International Seminar for Fire Safety of Facades, Paris (France), 2013
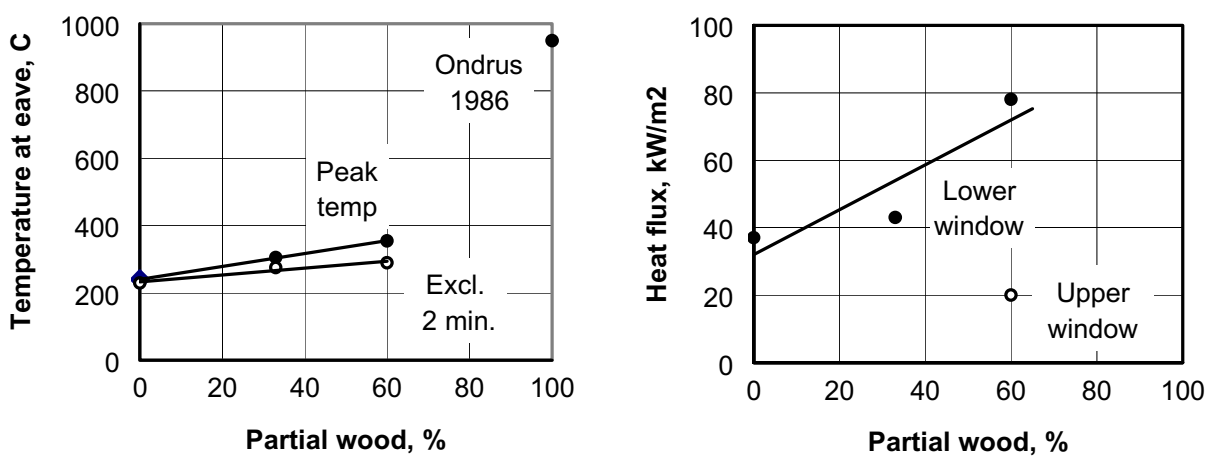

Figure 2. Maximum temperature at eave and maximum heat flux at windows for partial wood in facade. Critical levels $\left(500^{\circ} \mathrm{C}\right.$ and $\left.80 \mathrm{~kW} / \mathrm{m}^{2}\right)$ are not reached for partial wood up to about $60 \%$. Damage (charring) at upper window is failure criterion for $60 \%$ wood, see Figure 1.

Table 3. Fire retardant treated, FRT, wood, 100\%. Facade fire test data according to SP Fire 105.

\begin{tabular}{|l|c|c|c|c|c|l|l|l|}
\hline $\begin{array}{l}\text { Facade, } \\
\mathbf{1 0 0 \%} \\
\text { FRT wood }\end{array}$ & $\begin{array}{l}\text { Max temp. at } \\
\text { eave, }{ }^{\circ} \mathbf{C}\end{array}$ & \multicolumn{2}{|c|}{$\begin{array}{c}\text { Max heat flux, } \\
\mathbf{k W} / \mathbf{m}\end{array}$} & $\begin{array}{c}\text { Fire spread } \\
\text { charring) to } \\
\text { upper window }\end{array}$ & $\begin{array}{l}\text { Falling } \\
\text { parts }\end{array}$ & Note & Approved \\
\cline { 2 - 10 } & Peak & $\begin{array}{c}\text { Excl. } \\
\mathbf{2} \text { min. }\end{array}$ & $\begin{array}{c}\text { Lower } \\
\text { window }\end{array}$ & $\begin{array}{c}\text { Upper } \\
\text { window }\end{array}$ & & & & \\
\hline $\mathrm{X}$ & 335 & 295 & 45 & 10 & Yes, to lower part* & No & $\begin{array}{l}* \text { Failure } \\
\text { criterion }\end{array}$ & No \\
\hline Y & 285 & 260 & 24 & 6 & Yes, to lower part* & No & $\begin{array}{l}* \text { Failure } \\
\text { criterion }\end{array}$ & No \\
\hline ZA & 180 & 145 & 23 & 3 & No & No & & Yes \\
\hline ZB & 215 & 200 & 48 & 3 & No & No & Yes \\
\hline ZC & 260 & 220 & 45 & 7 & No & No & Yes \\
\hline $\begin{array}{l}\text { Require- } \\
\text { ments }\end{array}$ & - & $<500$ & $<80$ & $(<20) * *$ & No & No & $\begin{array}{l}* * \text { Suggested } \\
\text { level }\end{array}$ \\
\hline
\end{tabular}

A new European Technical Specification, CEN/TS 15912, with Durability of Reaction-to-Fire performance (DRF) classes has been developed in order to guide potential users to find suitable FRT wood products and encourage producers to supply competitive products [14]. The system consists of a control system for the durability properties of FRT wood products and suitable test procedures, see Table 5. The European system is based on a Nordic system and on experience from North America. For FRT façade claddings, the class for exterior applications is required, DRF EXT.

\section{Experience from natural weathering of FRT wood}

A long term experimental study [15] on the maintained reaction to fire performance of FRT wood products over time has been performed and includes accelerated ageing according to different procedures and natural weathering up to ten years. Main conclusions are:

- The hygroscopic properties are unchanged compared to untreated wood for most FRT wood products included in the study

- The reaction to fire properties of FRT wood may be maintained after accelerated and natural ageing if the retention levels are high enough 


\section{MATEC Web of Conferences}

\section{FRT Wood I}

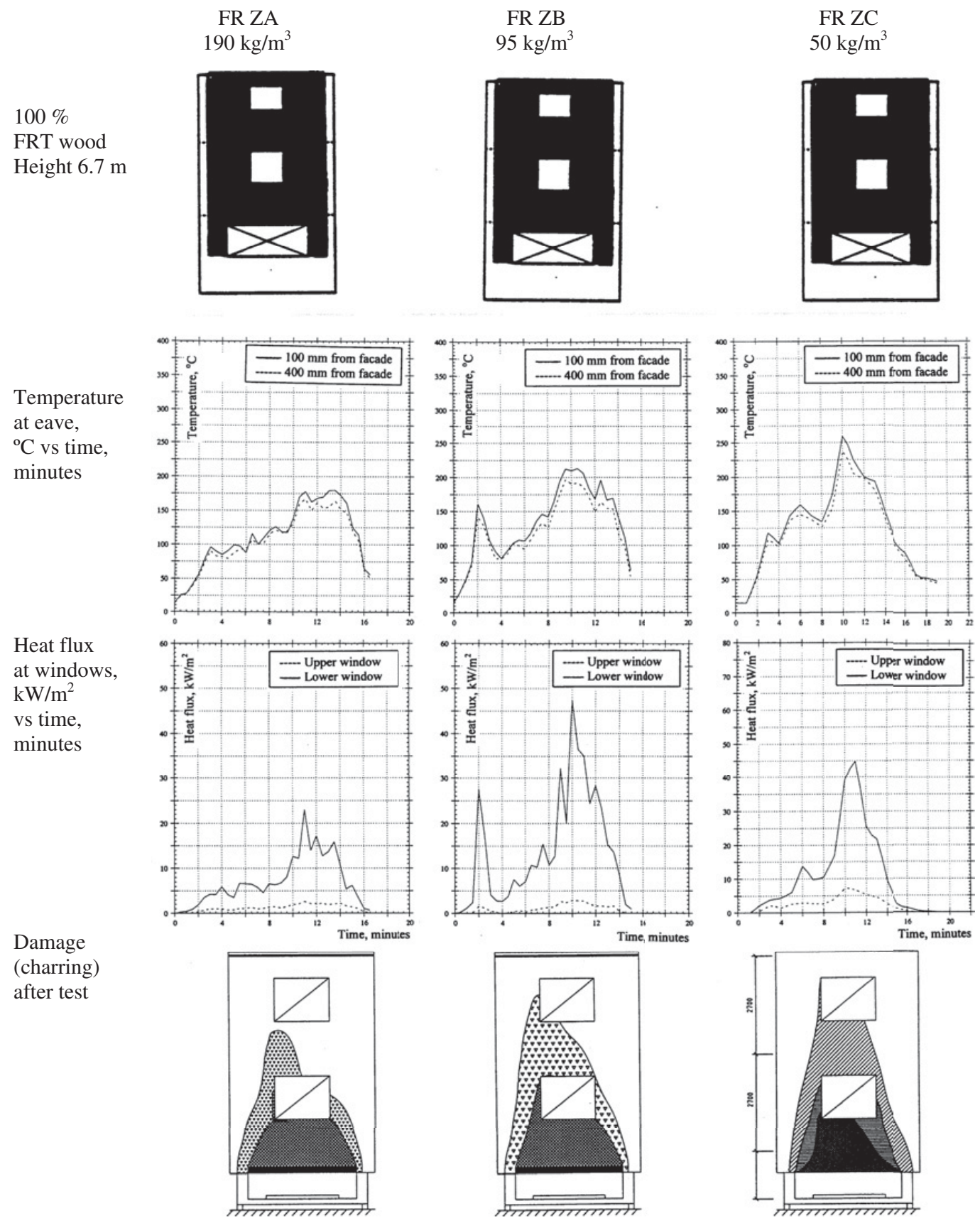

Figure 3. Facade tests according to SP Fire 105 and results for fire retardant $\mathrm{Z}$ at three retention levels.

- Several FRT wood products loose most of the improved reaction to fire properties during weathering

- Paint systems contribute considerably to maintain of the fire performance at exterior application. 
$1^{\text {st }}$ International Seminar for Fire Safety of Facades, Paris (France), 2013

\section{FRT Wood II}

FR Y

$45 \mathrm{~kg} / \mathrm{m}^{3}$
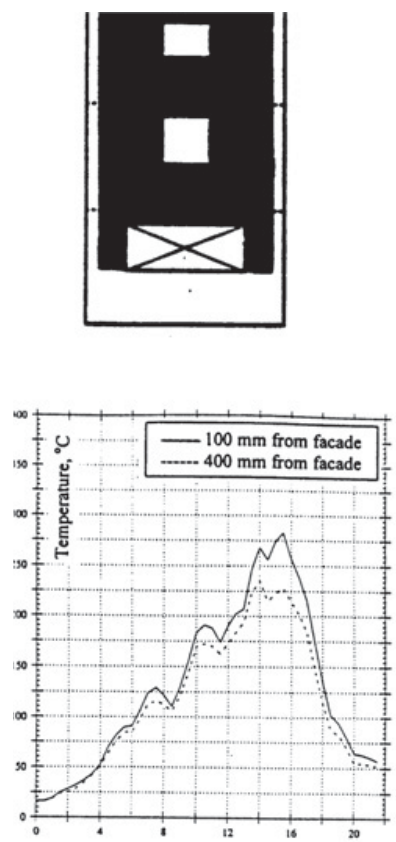

Heat flux at windows, $\mathrm{kW} / \mathrm{m}^{2}$

vs time, minutes

Damage

(charring) after test
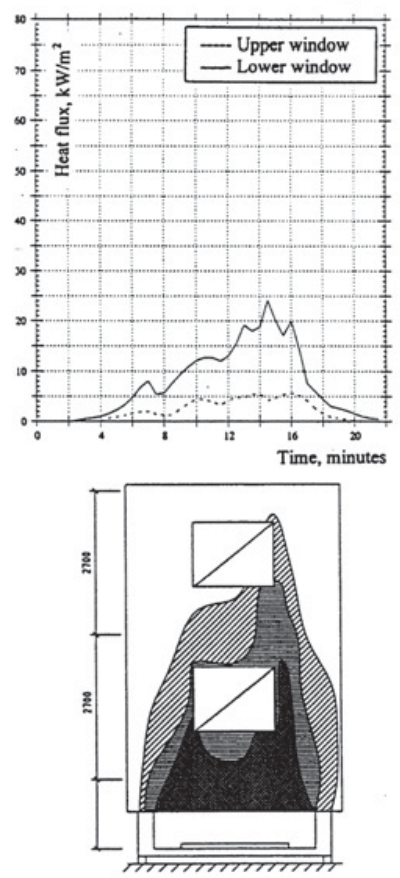

FR X

$25 \mathrm{~kg} / \mathrm{m}^{3}$
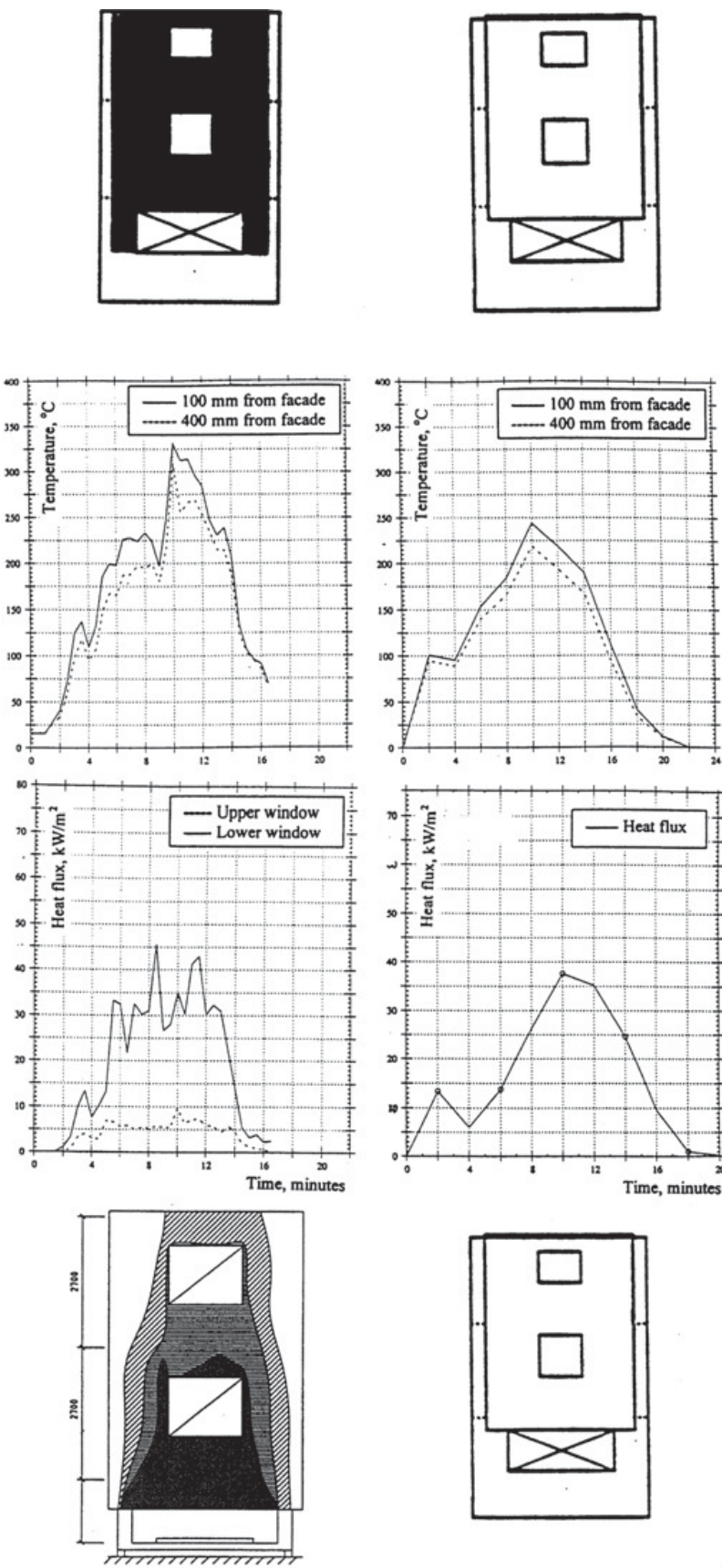
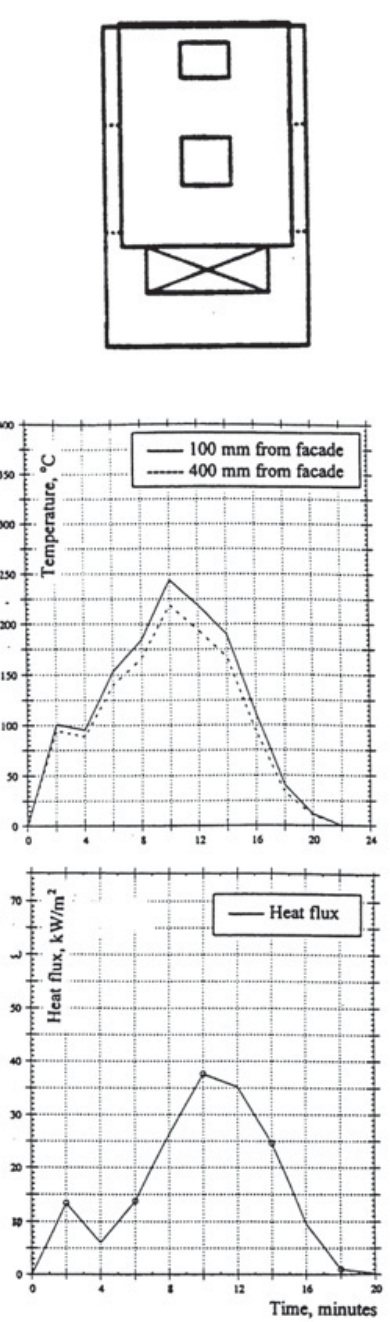

No cladding

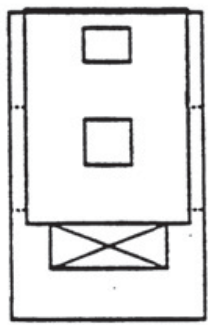

Figure 4. Facade tests according to SP Fire 105 for fire retardants $X$ and $Y$ (to the left) and for facade without cladding (to the right). 
MATEC Web of Conferences
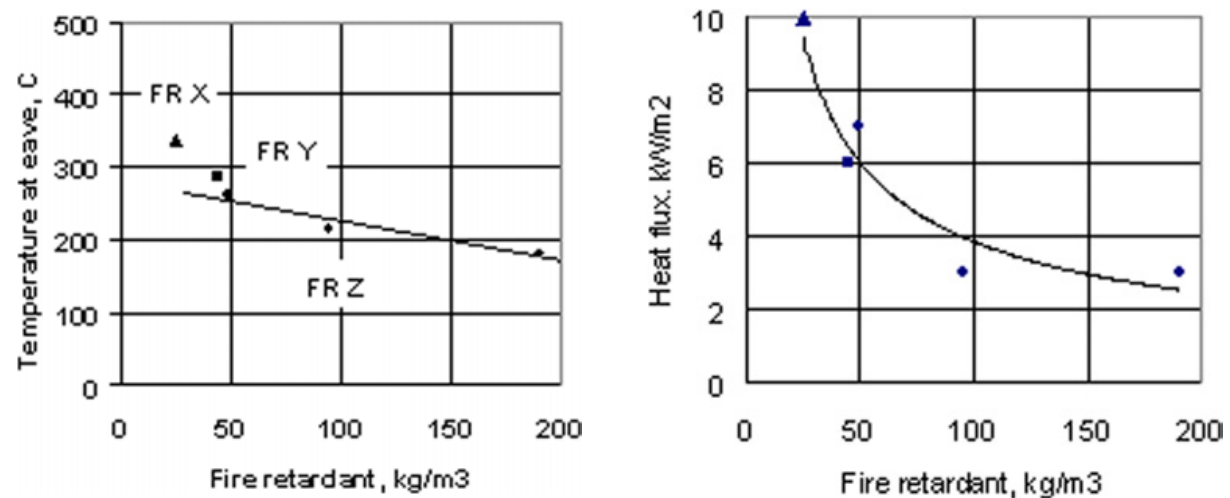

Figure 5. Influence of different retention levels for FRT wood. To the left: Maximum temperature at eave. Critical levels $\left(500^{\circ} \mathrm{C}\right)$ is not reached. To the right: Maximum heat flux level at upper window. Critical level $\left(20 \mathrm{~kW} / \mathrm{m}^{2}\right)$ is not reached.

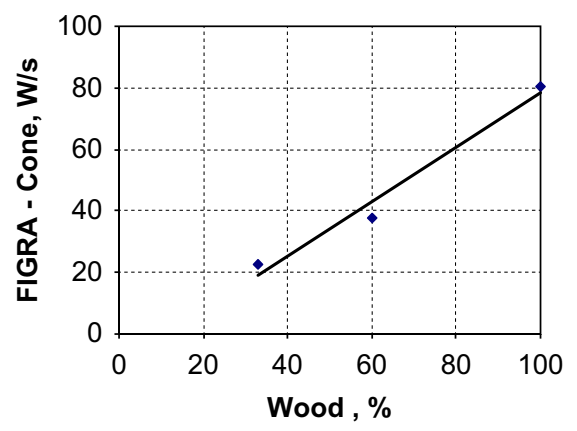

Figure 6. Comparisons between the cone calorimeter and façade fire data for different amounts of partial wood panel.
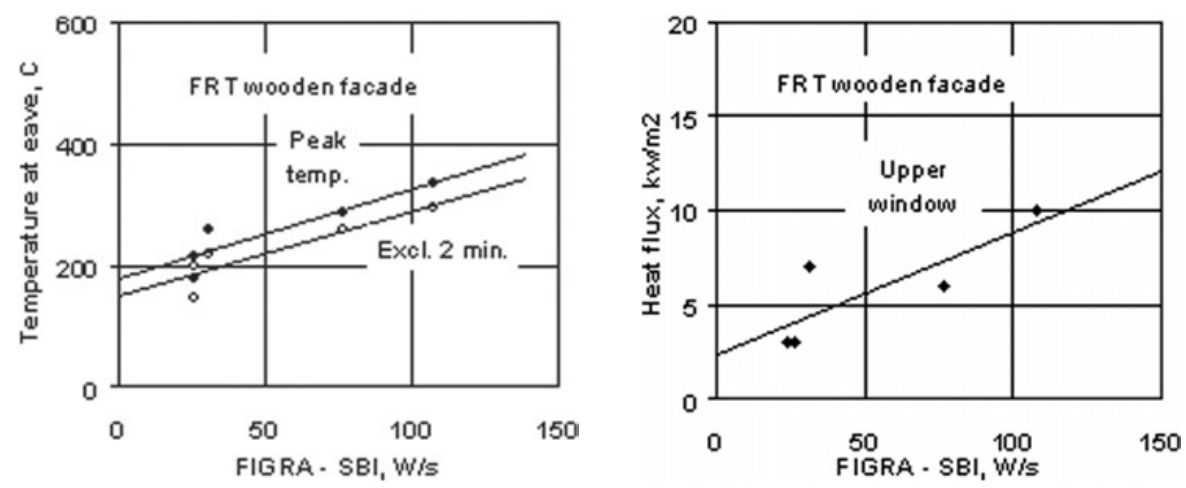

Figure 7. Direct comparisons between SP Fire 105 and SBI for FRT wood. To the left: temperature at eave in SP Fire 105 vs FIGRA - SBI. To the right: Heat flux at upper window in SP Fire 105 vs FIGRA - SBI. Critical levels $\left(500{ }^{\circ} \mathrm{C}\right.$ and $\left.20 \mathrm{~kW} / \mathrm{m}^{2}\right)$ are not reached. 
$1^{\text {st }}$ International Seminar for Fire Safety of Facades, Paris (France), 2013

Table 4. Comparisons of facade fire results with reaction to fire classification data.

\begin{tabular}{|c|c|c|c|c|c|}
\hline \multicolumn{2}{|c|}{ Fire retardant } & \multicolumn{2}{|c|}{ European class EN 13823, SBI } & Facade test SP Fire 105 \\
\hline Name & $\mathbf{k g} / \mathbf{m}^{3}$ & Main class & Smoke class & Drop class & Approved \\
\hline O & - & D & s1 & d0 & No \\
\hline X & 35 & B/C & s1 & d0 & - \\
\hline X & 25 & - & - & - & No \\
\hline Y & 55 & B & s2 & d0 & - \\
\hline Y & 45 & - & - & - & No \\
\hline ZA & 190 & - & - & - & Yes \\
\hline ZA & 170 & B & s2 & d0 & Yes \\
\hline ZB & 95 & - & - & - & - \\
\hline ZB & 105 & B & s2 & d0 & Yes \\
\hline ZC & 50 & - & - & - & - \\
\hline ZC & 65 & B & s2 & d0 & \\
\hline
\end{tabular}

Table 5. Requirements for DRF classes of FRT wood products according to CEN/TS 15912.

\begin{tabular}{|c|c|c|c|c|}
\hline \multirow[t]{2}{*}{ DRF class } & \multirow[t]{2}{*}{ Intended use } & \multirow{2}{*}{\begin{tabular}{c|} 
Fire class \\
Initial
\end{tabular}} & \multicolumn{2}{|c|}{ Performance requirements for different end uses } \\
\hline & & & Hygroscopic properties & $\begin{array}{c}\text { Fire performance after } \\
\text { weather exposure }\end{array}$ \\
\hline sis & Short term & Fire class & - & - \\
\hline (intr) & Interior, dry & $-"$ - & $\begin{array}{c}\text { Limited moisture content, } \\
\text { no salt crystals }\end{array}$ & - \\
\hline (INT2) & Interior, humid & - " - & - " - & - \\
\hline$($ INT2) & Exterior & - " - & $-"$ - & $\begin{array}{l}\text { Maintained fire } \\
\text { performance }\end{array}$ \\
\hline
\end{tabular}

\section{STRUCTURAL MEASURES AND FIRE STOPS IN FACADES}

Structural measures for fire stops in façade claddings are very important for the overall fire safety in all types of façades [1]. Some examples are given in Figure 8. Overhanging fire stops and fire stops behind the panelling help to restrict the spread of fire on and behind façades, reducing the spread of fire over several storeys. Fire stops in facades have the following effects:

- prevention of stack effect in the rear ventilation void

- deflection of flames from the façade surface

- reduction of fire input inside the rear ventilation void.

The main threat from a fire in the ventilation gap of a façade is that it may spread to other spaces, such as apartments or attic/roof void spaces, unless it has been prevented by special eave structures.

\section{FIRE SAFETY DESIGN WITH SPRINKLERS}

The main aim with sprinkler installations is to save lives and property. In addition, sprinklers may allow for an alternative design of buildings. Requirements on passive fire protection to provide means of safe egress may be at least partly reduced, see Figure 9. This will facilitate a more flexible use of alternative 


\section{MATEC Web of Conferences}
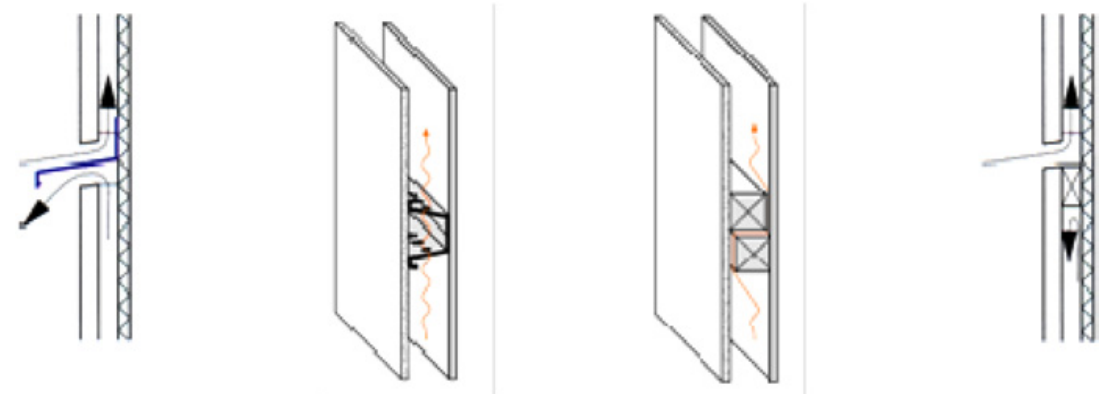

Figure 8. Examples of fire stops in facades.

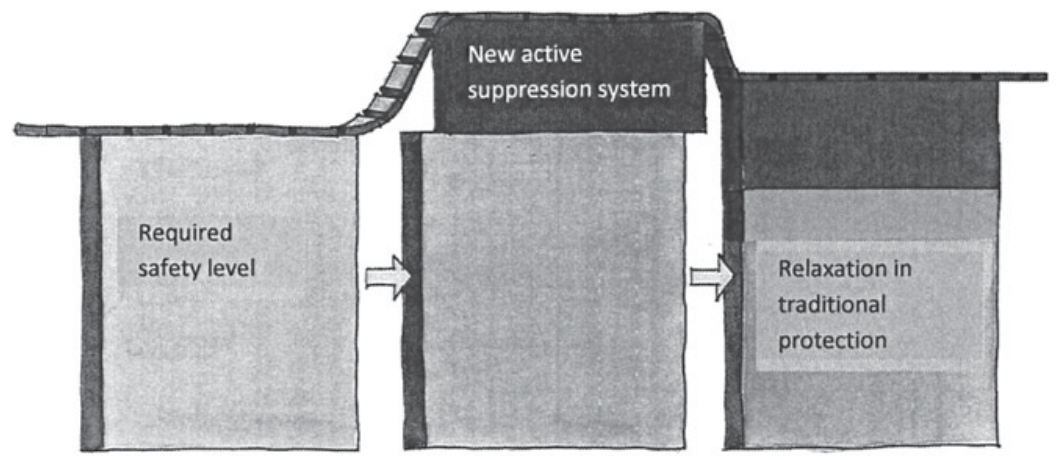

Figure 9. Principle for fire safety design by sprinklers. Increased fire safety by sprinklers may lead to relaxations in the passive fire protection features, and still fulfil the same or higher safety level [1].

building products. Wooden facades may, for example, be used in sprinkled buildings, which is logical since the risk of flames out of a window from a fully developed fire is eliminated. The implementation of alternative fire safety design with sprinklers may vary between countries. In Sweden four alternatives have been verified, if sprinklers are installed [16]:

- Combustible façade cladding up to eight storeys

- Decreased requirements on surface linings in apartments in multi-storey buildings, down to class D-s1,d0

- Decreased requirements on fire spread through windows in the same building

- Increased walking distance in escape routes.

Several of the recent multi-storey timber buildings in Sweden have sprinklers installed and wooden claddings.

\section{CONCLUSIONS}

The overall conclusions from this study are

- SP Fire 105 is a useful tool to evaluate full scale fire behaviour of facade claddings. However, the visual observations should be complemented with more objective data.

- The fire damage (surface charring) at the upper window is the main failure criterion for wooden facades, not the temperature at the eave or the heat flux at the lower window.

- Partial wood up to about $50 \%$ fulfil the requirements, but the exact amount depends on the geometrical configuration of the wood in relation to the windows. 
$1^{\text {st }}$ International Seminar for Fire Safety of Facades, Paris (France), 2013

- A fire shield above a window may stop the fire spread and allow $100 \%$ wood to be used.

- Good agreement has been found between flame spread in the full scale SP Fire 105 test, the European intermediate scale SBI test and the small scale cone calorimeter.

- The amounts of FRT chemicals are essential for fulfilling the fire performance criteria.

- The reaction to fire durability class DRF EXT is required for FRT wood façade claddings.

- Only few FRT are able to maintain the fire properties over time and a protective coating is needed.

- Fire stops in cavities of any façade system are essential to avoid rapid flame spread.

- Sprinkler allow for an extended use of wood as façade claddings.

\section{References}

[1] Fire safety in timber buildings - Technical guideline for Europe. SP Report 2010:19, Stockholm, Sweden 2010.

[2] EN 13501-1. Fire classification of construction products and building elements - Part 1: Classification using test data from reaction-to-fire tests. European Standard.

[3] SP FIRE 105. External wall assemblies and facade claddings. Reaction to fire. Fire test method, Swedish National Testing and Research Institute, Issue No 5, Borås, Sweden, 1994.

[4] Hakkarainen T, Oksanen, T. Fire safety assessments of wood, Fire and Materials 26 7-27, 2002.

[5] Korhonen T and Hietaniemi J. Fire Safety of Wooden Facades in Residential Suburb Multi-Storey Buildings, VTT Working paper 2, Espoo, Finland, 2005.

[6] Wade C. Fire performance of external wall claddings under a performance-based building code. Fire and Materials, 19, 127-132, 1995.

[7] Nystedt F. Case Studies on the Verification of Fire Safety Design in Sprinklered Buildings. Department of Fire Safety Engineering and Systems Safety, Lund University, Report 7035, 2012.

[8] Fire safe timber buildings - Nordic-Baltic guideline version 3 (in Swedish). SP Report 2012:18, Stockholm, Sweden, 2012.

[9] Östman B. Fire performance of multi-storey wooden façade claddings. SP Report 2005:16, Stockholm, Sweden 2005.

[10] SP Test Reports (all in Swedish): Report 98R1 3160: Fire testing of facade cladding. Wood laths; Report 98R1 3167 A, B, C and D: Fire testing of facade cladding. Non combustible areas and fire shield; Report R1 8505: Reference values; Report P001919 A, B and C: Fire testing of facade cladding. FRT wood panels, Borås, Sweden, 1999-2000.

[11] EN 13823. Reaction to fire test for building products - Building products excluding flooring Exposed to the thermal attack by a Single burning Item (SBI test). European Standard.

[12] ISO 5660. Fire tests - Reaction to fire - Part 1: Rate of heat release from building products. International standard.

[13] Östman B, Voss A, Hughes A, Hovde P J, Grexa O. Durability of fire retardant treated wood at humid and exterior conditions. Review of literature. Fire and Materials, 25, 95-104, 2001.

[14] CEN/TS 15912. Durability of reaction to fire performance of FRT wood-based products in interior and exterior end-use applications, European Technical Specification, 2012.

[15] Östman B, Tsantaridis L. Durability of the reaction to fire performance for FRT wood products in different end use applications - a ten years report, Proc. 12th International Conference on Durability of Building Materials and Components, XII DBMC, Porto, Portugal, April 2011.

[16] Nystedt F. Verifying Alternatives in Buildings with Fire Sprinkler Systems. Department of Fire Safety Engineering and Systems Safety. Lund University, Report 3150, 2011. 